Dorota Dakowska et Kathia Serrano-Velarde, "European Higher Education Policy ", in: Hubert Heinelt et Sybille Münch (dir.), Handbook of European Policies: Interpretive Approaches to the EU [Handbooks of Research on Public Policy, sous la direction de Frank Fischer], Edward Elgar, à paraître en 2017.

\title{
European Higher Education Policy
}

\section{Introduction}

In 2000, European ministers called on Europe to become "the most competitive and dynamic knowledge-based economy in the world, capable of sustainable economic growth with more and better jobs and greater social cohesion" (European Council 2000). Since economic development is contingent on the innovative capacities of its workers, education became the key to both economic and social sustainability in Europe. The all-encompassing Lisbon Agenda of 2000 that refined the priorities and working mechanisms of policy action in Europe was thus a turning point for higher education. It broke with the principle of subsidiarity that had been imposed on social policy since the Maastricht Treaty. By stressing the importance of tertiary education for economic growth, Lisbon paved the way for the development of a genuine EU policy agenda.

The following chapter sheds light on the construction of a European higher education policy. Beginning with the historical context, we wish to stress the importance of the intellectual and political climate that has led EU member states to reconsider their national take on educational policies and to contemplate joint action. We will also take a closer look at the structural arrangements and actor-constellations that have developed over time and explain some of the political intricacies of European higher education policy. We believe that an interpretive perspective on educational policymaking provides the adequate tools to understand how political practice undermines the formal division of competences between the Commission and the member states. Interpretive accounts enable us to capture the emergence and transnational circulation of narratives concerning higher education reform and to understand why European governments feel increasingly bound by rules developed outside of the realm of domestic policy.

This contribution adopts an interpretive approach as it takes into account both the structural and the discursive dimension of the construction of higher educational issues at the European policy level. Following Foucault (1966), researchers have been interested in the emergence of a dominant discourse and its use by hegemonic groups. Frank Fischer, for instance, argues that "the creation of social knowledge and power are intimately linked. To act together, a 
human community must come to some agreement on what vision of reality it will accept as both factually correct and normatively legitimate. Such rhetorical closure on the definition of reality establishes the foundation of social order" (Fischer 1995, p. 208-209) and allows some groups to take precedence over others. The case of European higher education policy requires special analytical caution, as it is a policy field with fluid boundaries that mobilizes a variety of actors. Firstly, higher education has historical connections to different policy areas such as research, social, and economic policies. As such, political forces have, over time, framed European higher education policy beyond the mere sphere of education. Secondly, as education falls under the subsidiarity clause of the Amsterdam treaty, higher education remains, formally, beyond the political reach of the Commission. Therefore, we must analyze how the EU managed to gain credibility and competencies in an area where its formal competencies were legally restricted. In order to "do" higher education policy, Commission officials in higher positions need to build coalitions with governmental representatives of member states, who seek an external source of legitimacy for their domestic reforms, organized stakeholders, professional organizations, or representatives of the academic community.

This chapter is structured in three parts. The first part focuses on the emergence of a European higher education policy. In order to understand the agency structure behind contemporary Europeanization processes in higher education, it is imperative to reconstruct the historical path that led to the institutionalization of higher education policy actors at the EU level. We thus develop a socio-historical account that sheds light on the interaction between political actors at different levels. Particular attention will be paid to the importance of other international organizations - such as the OECD - in the development of a European higher education agenda. In the second part, we critically discuss the scholarship that addresses the European Commission's educative activism. We argue that the interpretative approach provides evidence for the importance of framing, mutual adjustment, and learning processes at the European level, thereby broadening our understanding of policymaking practices in the EU. The third and final part of this chapter reviews alternative Europeanization scenarios by examining more recent intergovernmental reform initiatives such as the Bologna Process. By analyzing how a voluntary coordination of higher education policies such as the Bologna Process became increasingly binding for its members due to the Commission's policy activism, we show how transnational reform arenas overlap, challenge, and complement one another. Indeed, current European higher education policy is the result of a coevolution of 
supranational and intergovernmental policy initiatives marked by power struggles, competition, and strategic convergence.

\section{The Emergence of European Higher Education Policy}

\section{The international dimension of education policy}

The emergence of a European higher education policy ought to be seen against the backdrop of the increasing interest in education by international economic players such as the World Bank and the OECD. Drawing on the insights of human capital theory developed by the economist Gary Becker (1962), these supranational institutions came to understand education as a major factor for national economic growth, political stability, and social equality. As a result, education has been an integral part of their policy agenda since the early 1980s. The World Bank began to consider access to primary and secondary education as major criterion for credit allowances to developing countries (Heyneman 2003). Much in the same vein, the OECD incorporated educational issues into its economic agenda by the end of the 1980s, thereby raising awareness (among developed countries) that the educational level of a population is directly linked to national issues of economic competitiveness and welfare (Niemann and Martens 2015). Further, it is important to note that the OECD's rise to a leading position in educational policymaking is undoubtedly linked to its statistical competence.

The OECD began to compile statistical information on educational systems in the 1960s (Henry et al. 2001). Although a Working Party of the Education Committee on Educational Statistics and Indicators was set up in 1973 to develop a general framework of indicators measuring the economic and social impact of education, it was not until the late 1980s that the accountability movement in the OECD member states managed to push for systematic and more detailed information on the performance of national education systems. As a result, the INES project (International Indicators and Evaluation of Educational Systems) was launched in 1988, leading to the yearly release of cross-country comparative statistics in the authoritative "Education at a Glance" report (Martens 2007). By 2000, the OECD had implemented an influential international monitoring system that tracked the educational performances of student populations in all OECD countries: the Program for International Student Assessment (PISA).

Recent scholarly work shows that this readymade toolbox for policy evaluation has had a direct impact on national reform strategies in most European member states (Knodel et al. 2013). There is no doubt that the OECD's production of performance data is a typical 
example of "governing by numbers" (Miller 2001; Grek 2009). Indeed, from an interpretive point of view, the use of statistics is not neutral and must be placed in its political context if we are to understand its effect on the production of meaning: "lexis and statistics, interpretation and practical proposals are complementary aspects in the political and ideological activity of the European Commission" (Cussó 2008, p. 41). In this perspective, Martin Lawn and Sotiria Grek (2012, p. 117) show that the OECD has become "a significant actor in the governance of the European education space" thanks to the data it provides and to its close cooperation with the European Commission.

\section{The rise of EU higher education policy}

While most of the data used in the EU's indicators report for the Lisbon Strategy are provided by the OECD, the European Commission covers a large part of EU member states' national costs for participating in OECD surveys (Lawn and Grek 2012). The European Community's concern for tertiary education dates back to the beginnings of the European integration process. Anne Corbett's (2005) seminal work reminds us that the first attempts to set up a European university can be found in the 1957 Treaties of Rome. The Euratom Treaty thus stipulated that an "institution of university status shall be established" at the European level (Croché 2010, p. 70). Although the European University Institute in Florence was founded 15 years later, the history of European Community policymaking in education is widely understood to have started in 1974, with the Resolution of the Ministers of Education (Neave 1984). The resolution not only set the guiding principles for European cooperation in higher education (Council 1988), it also established a division for higher education within DG Research, Science, and Education. By creating a legal and political space for European action in the realm of education, the ministers laid the first stone for the implementation of an action program for higher education targeting issues of student mobility and educational cooperation across European borders (McMahon 1995). Early policy documents stressed the importance of educational achievement for both economic and social goals, thereby mirroring the zeitgeist of international education politics.

Albeit operating in the gray zones of the European Community's legal competence, the educational division managed to launch a number of successful joint projects and mobility incentives such as the Erasmus Program (1987). However effective these programs were in promoting an educational ideal that combined both economic and humanist perspectives on education, it was not until the 1992 Treaty of Maastricht that the legal and financial situation of European higher education policy was settled. When the opportunity for rethinking the 
Community's legal base arose with the inter-governmental conferences leading up to the Treaty of Maastricht, the Commission's President, Jacques Delors, and several member states took the view that education was to be firmly anchored within a subsidiary framework and that EU action was appropriate to the extent that it complemented national reform initiatives (European Council 1992, Articles 126 \& 127). The Maastricht Treaty thus consolidated a "constitutional asymmetry between policies promoting market efficiencies and policies promoting social protection and equality" (Scharpf 2002, p. 645). In other words, the economic project of creating a single market took precedence over the social protection of European citizens and workers.

The redistributive and subsidiary character of education and research was particularly problematic when it came to establishing EU executive power in the field of higher education (Bache 2006; Ertl and Phillips 2006; Banchoff 2002). In fact, universities did not find their place within the European agenda until the 2000 Lisbon Council of European Ministers. Largely inspired by the economic approach to educational issues promoted by the OECD, the ministers' declaration on the introduction of the Lisbon Agenda urged the European Union to revisit its educational agenda. Even though leading European countries were governed by center-left governments at the time, Lisbon clearly prioritized the economic value of knowledge and innovation over the more humanist traditions it had formerly asserted in the framework of its educational policies. Instead, universities were made responsible for achieving the long-standing and complex goal of a unified Europe: to combine an economic agenda with a social policy framework for all European citizens. Without a doubt, the Lisbon Agenda was a turning point for higher education and research policies, which attracted increased political attention. Not only did the pervasive notion of economic competitiveness change the way in which issues surrounding higher education were formulated, but the incremental introduction of policy tools adapted from the open method of coordination (OMC) framework propelled EU higher education policy into a whole new era of political activity (de Ruiter 2010; Ertl 2006). Through the introduction of education indicators, benchmarking initiatives, and deliberative strategies, higher education became a policy field that was meant to advance through policy learning and the individual commitment of member states (Radaelli 2009). As such, it does not come as a surprise that policy making at the European level is characterized, in higher education, by a great degree of policy borrowing and diffusion across policy arenas.

Regarding issues of diploma recognition and quality assurance, for instance, the European Commission built a large part of its policy agenda on the work of the Council of Europe 
(CoE) (Jorge de Melo 2013). The CoE was the first international organization to develop a legal, intergovernmental framework for the recognition of qualifications through a series of intergovernmental conventions adopted in the 1950s. One of the central agreements sustaining international student exchanges, the 1997 "Lisbon Recognition Convention", has been implemented jointly by the CoE and UNESCO. Through its involvement in the Bologna Process and its substantial contribution to the development of a "Framework of Qualifications for the European Higher Education Area" (Jorge de Melo 2013), the CoE has become a valuable ally for the European Commission. The close cooperation between the $\mathrm{CoE}$ and the Commission following the Bergen ministerial conference in 2005, however, had surprising repercussions, as most of the policy work came to be attributed to the Commission.

The qualification framework is just one example of how the European Commission mobilizes its network to further the visibility of higher education issues at the European level. Indeed, a substantial part of the policy measures developed in cooperation with other international organizations came to be relabeled as EU initiatives, so that, over time, the European Commission became a central player in the Europeanization of educational policy issues. The discursive activism of the Commission, which combines framing strategies and political networking, is at the heart of European higher education policy and is of particular interest for interpretive research designs. By accounting for the discursive dimension of the policymaking process, we can come to understand how the Commission has been able to seize political opportunities and advance its competence and authority in a field that - by law - lies well beyond its formal prerogatives.

To conclude, there are two important lessons that interpretive researchers learn from European higher education policy and its history. The first lesson concerns the central role of the European Commission in constructing a policy field out of borrowed elements and clever coalition-making at both the transnational and the governmental level. This is why the literature employs the concept of "policy entrepreneurship" to describe the Commission's actions in this particular policy field (Corbett, 2005). The second lesson pertains to the performative dimension of European policymaking: the strategic use of policy instruments such as statistical data, indicators, and benchmarking in the fashioning of a political agenda.

\section{European Higher Education Policy: Between Structural and Interpretive Accounts}

In the following section, we discuss different approaches to European higher education policy beyond the traditional notions of Europeanization as entailing supranational competence 
building or transnational convergence scenarios. The complexity of the European policy arena in the realm of higher education has given rise to studies that problematize the coevolution of structure and discursive agency. One of the main challenges in understanding the Commission's policy activism is linked to its limited formal prerogatives in the higher education area. However, Bache (2006, p. 236) has noted that "EU institutions do not require a formal shift of policy competence to exercise influence". Consequently, formalist arguments, which posit that the Commission does not interfere in the areas that fall under the principle of subsidiarity, cannot account for the more practical dimension of day-to-day policymaking. European higher education policy evolved incrementally and can be considered the product of pragmatic coalition-making, the entrepreneurial spirit of higher EC officials, and the performative effects of policy instruments.

Two strands of literature have been of particular importance in deciphering the gray zones of European policymaking in the field of higher education. We locate a first contribution to the understanding of European higher education policy in studies that take a historical or sociological approach to the structural and procedural expansion of the European Commission. According to the principle of subsidiarity, the Commission only has the right to propose educational initiatives that complement national policymaking competences. This has not stopped the Commission from investing in related policy areas, such as vocational education, where it has enjoyed the right of initiative since the Treaties of Rome (Article 128). Expanding the European Economic Communities' competence into the domain of higher education was thus an act of reframing higher education policy as some sort of vocational training. This raised a fair amount of criticism, as it sealed the utilitarian conceptualization of education focused on the acquisition of skills that are useful in the job market. Yet, the relabeling of higher education as vocational training turned out to be an efficient way to push forward initiatives promoting students' mobility, such as the Erasmus program, which the Commission launched in 1987.

Although higher education policymaking has a strong discursive component, the expansion of the Commission's competence can only be understood against the backdrop of the political entrepreneurship exhibited by higher EC officials such as Hywel Ceri Jones, who was head of the education and youth division between 1973 and 1988. In her historical account of the emergence of EU higher education policy, Corbett underscores Ceri Jones' role, stating that his task was to "unofficially [...] try and get Community competence for the non-Treaty sector of education" (Corbett 2005, p. 155). Ceri Jones was supported by Commissioner Peter Sutherland (in charge of Competition, Social Affairs, Education, and Training), who, since his 
nomination in 1985, had furthered the Comett and Erasmus programs as a complementary strategy to the single market project. Higher education, Jones felt, complemented the economic project in the sense that it was essential to the training of the future European workforce and a means to form a European-minded citizenry. Thus, the making of European higher education policy reveals the importance of entrepreneurship in identifying opportunities, developing discursive strategies, and developing sustainable alliances within the European Commission as well as between the Commission and stakeholders (Normand, 2010). It is important to note that the creation of a European policy space clearly transcended the inter-institutional power games between the European Commission and the Council indeed, it involved an "intertwined and captivated Europeanized population of experts, practitioners and professionals who contribute to the production of standards in the EU" (Lawn and Grek 2012, p. 70). We shall return to this argument in the next section, when discussing the interaction between the Lisbon Agenda and the Bologna Process.

A second account of European higher education policy focuses on the performative aspects of EU policymaking. Scholars working in this line of research argue that discursive practices and the introduction of specific policy instruments have real-time implications on the development of actors' policymaking competences. Cussó's (2008) lexicometric analysis of EU policy documentation regarding education and training (1995-2003), for instance, emphasizes the different tenets attached to the notion of a "knowledge society". She shows that the socioeconomic paradigm linked to the vision of a "knowledge society" is frequently associated with terms such as "work", "employment", and "skills", considered as factors of competitiveness. Despite strategic euphemizing through the use of terms such as "lifelong learning" and "flexibility", Cussó's interpretation of the Commission's discourse reveals a project whose main priority is “education's adaptation to job market needs by developing strategic skills and by increasing private investments" (Cussó 2008, p. 51). In an interpretive approach that combines a discursive analysis of policy documentation and interviews with its authors, Serrano Velarde's (2014a) analysis of the "framing strategies" of EC officials in the area of higher education shows how the slogan of a European "knowledge economy" promoted by the Lisbon Strategy has been systematically used to enhance the Commission's legitimacy and visibility in higher education. By analyzing the conditions in which these policy texts are actually produced, she draws attention to the underlying rhetorical techniques of the framing effort and observes that "agents are aware of their institutional predicament" (Serrano Velarde 2014a, p. 12). This being said, focusing on the role of the European Commission in initiating and shaping European higher education policy only provides us with 
part of the picture. Indeed, researchers interested in the introduction of the open method of coordination $(\mathrm{OMC})$ in the realm of education have highlighted the necessity of investigating how the discursive construction of educational benchmarks and indicators influences reform processes in EU member states (Alexiadou et al. 2010). Much in the line of Lascoumes and Le Galès (2007), this scholarship argues that public policy "instruments" such as mobility programs, indicators, or benchmarking are not neutral devices. Rather, they affect both public policy and institutional arrangements in ways that cannot be anticipated by policymakers. By adopting the $\mathrm{OMC}$ for educational policies, the European Commission pursues a "powerful strategy for shaping education policy space around 'learning' since it aims to achieve common objectives in education, which include goals that tie 'learning' to the economic and social objectives of the Lisbon strategy" (Alexiadou et al. 2010, p. 346). Since the OMC is an open coordination strategy that cannot enforce policy results, it is worth taking a closer look at how it operates. The OMC works by (1) stipulating common policy objectives for a number of countries, (2) monitoring national progress toward these objectives and (3) engaging stakeholder dialogue for the diffusion of good practice. As a result, national policy priorities are subordinated to a common agenda. Yet, the convergence scenario anticipated by this type of policy instrument aims first and foremost at developing common educational goals. Policy outcome is the result of a learning process in which member states ought to adapt policy instruments and objectives to match their institutional infrastructure. This observation does not imply that all member states share the same outlook on OMC benchmarks and perspectives on education. While new member states such as Slovenia, which has experienced strong pressure to reform its public administration during the EU accession process, are more open to adopting the European discourse, the United Kingdom has always been more reluctant to comply with the common objectives (Alexiadou et al. 2010, Dakowska and Harmsen, 2015). Instead, UK officials have constructed the image of a perfect "fit between the UK and OMC objectives" and claimed to being a standard-setter for other countries (Alexiadou and Lange 2013). In addition, benchmarks affect EU member countries in different ways. While many EU countries have met the goal that "at least $40 \%$ of people aged 30-34 should have completed some form of higher education" (European Commission 2014) since the 1990s, this represents a considerable challenge to newer member states such as the Slovak Republic, where $18 \%$ of the population has a higher education degree (OECD 2016). The benchmark on student mobility stipulates that "at least $20 \%$ of higher education graduates and $6 \%$ of 18-34 year-olds with an initial vocational qualification should have spent some time studying or training abroad" (European Commission 2014). Although this objective is 
unrealistic in many European education systems, it has powerful policy effects in terms of resources spent on academic internationalization strategies. Domestic differences in the framing of EU policy recommendations point to the importance of interpretative approaches to the OMC. Only by comprehending the national adaptation and instrumentalization of EU policy can we grasp the complexity of national contexts beyond the common expectation of policy convergence.

Due to the multilevel nature of European higher education policy - which is shaped and promoted at the EU level and interpreted, redesigned, and enacted at the domestic level - an interpretive research agenda needs to account for the existence of multiple stakeholders who act across policy arenas to co-construct a policy space (Normand 2010; Gornitzka 2010). The Bologna Process provides a useful case study to analyze the tensions between the European, intergovernmental, and domestic levels; it will help us to understand how these European narratives are perceived and translated in old and new EU member states, as well as beyond EU borders.

\section{What Does Bologna Tell Us about Europeanization?}

The following section supports our argument with detailed insights into a single European policy framework: the Bologna Process. Drawing on the existing literature and our own investigations, we discuss the interdependence of transnational policy arenas in European higher education and the implications of European policy coordination for national policymakers.

In order to appreciate the full scope of the paradigm shift that took place in European higher education, we need to take the wider policy setting into account: a few years before the Lisbon Agenda stirred up higher education policymaking at EU level, the education ministers of France, Great Britain, Germany, and Italy initiated a reform movement that came to be known (and renowned) as the Bologna Process. The Bologna Process, launched in 1999, is a series of ministerial meetings, working groups, and intergovernmental agreements between 48 European countries designed to ensure the transferability of degrees and standards of higher education qualifications. Reform goals entail guidelines regarding the harmonization of qualification degrees, the introduction of a credit point system as developed by the European Commission in the framework of the Erasmus program, and quality assurance measures. The Bologna Process thus unveils a series of paradoxes in the policymaking process at the European level and raises one important question: how does the coevolution of $\mathrm{EU}$ policymaking and the intergovernmental reform process work? 
We argue that an interpretive approach to this phenomenon enables researchers to reconstruct a more pragmatic account of what has happened, thereby rendering "tacit knowledge explicit", making "silenced discourses speak" and addressing "questions of power" (Yanov and Schwartz-Shea 2006, p. xx). At first sight, it seems that the intergovernmental Bologna Process and EU higher education policy share an important number of reform interests. However, while Bologna rapidly evolved into a full-grown intergovernmental plenum dedicated to the "harmonization" of European higher education (Sorbonne Declaration 1998), the European Commission was initially relegated to the rank of "observer" (Ravinet 2008), with little formal influence on the political decision-making process. Although Bologna Process member states were initially suspicious of the Commission's agenda and wished to avoid giving the impression of yet another EU initiative, the Commission has made itself useful by providing the necessary funds for the policymaking process: not only does it cover the costs of the standing secretariat for the intergovernmental reform process, but it also finances expert networks and organizations such as the "European Network for Quality Assurance"/ENQA (Serrano Velarde 2014b). In the same vein, the Tuning project, which has been funded by the Commission since 2000, provides financial support for the reformulation of national education goals and curricula in terms of competences and "learning outcomes" with the aim to "link the political objectives of the Bologna Process and at a later stage the Lisbon strategy to the higher educational sector" (Tuning educational structures in Europe). This is how the European Commission became a central actor in the intergovernmental reform process: it has been an official member of the Bologna Process since 2001, and was given voting rights during the Bergen ministerial conference in 2005. As a result, it has become a difficult task to differentiate between EU policies and intergovernmental reform projects in the realm of European higher education. What does this tell us about the nature of Europeanization in this specific policy field?

Research on the Bologna Process has dealt quite extensively with issues of Europeanization in higher education (Curaj et al. 2012; Klemencic 2013). Besides policy-oriented or prescriptive publications, this scholarship has also engaged in a critical debate on the nature of the policymaking process and the role of the European Commission therein (Dale and Robertson 2009). Some authors argue that strictly EU-centered dynamics play a secondary role, instead emphasizing the intergovernmental character of European higher education reforms (Muller and Ravinet 2008). Others highlight the role of international organizations such as the Council of Europe or UNESCO (Croché 2009), and the increasingly dominant role of the European Commission in "steering" the Bologna Process (Croché 2010). Apart from the debate on the 
relative weight of national and international institutions, there is also disagreement regarding the overall significance of the Bologna Process as regards national reform processes (Charlier 2009). It is all the more remarkable that evaluative accounts regarding the meaning and significance of the Bologna Process for institutional change at the national level vary substantially without ever engaging in a productive dialogue. For some, "the development of a European action to promote students' mobility is unanimously recognized as positive" (Ravinet 2009, p. 353); for others, the Bologna Process has always been subordinated to "economical issues that are presented as 'imperatives', the existence of a global competition between higher education institutions and the necessity to construct a European market for tertiary education" (Garcia 2007, p. 81).

The policy narratives disseminated by the Commission must be analyzed against the backdrop of its institutional expansion strategy. The Commission's capacity to enroll stakeholders that depend on its material resources, data, and legitimizing power is of paramount importance to the successful expansion of its competences in the field of higher education. While it is acknowledged that European policy initiatives in education can be conceptualized as "EU policy" regardless of their institutional origin (Walkenhorst 2008), the entrepreneurial nature of EC policymaking deserves closer interpretative scrutiny. The Commission's "power of the purse" is not merely a material or technical issue (Batory and Lindstrom 2011); rather, it sheds light on the enrollment processes of a domestic clientele (i.e., universities) that is ready to challenge or lobby its own government in order to change the existing national legislation. The domestic stakeholders' support of community activities in education is linked to the fact that the costs of "opting out can be prohibitive" as far as their chances to be granted EU funds is concerned (Batory and Lindstrom 2011). Authors interested in the strategic intermediary level between the Commission and the national governments have looked into the functioning of national and transnational stakeholder groups at the European level, such as the Bologna Follow Up Group (Lažetić 2010) or expert groups set up as part of the open method of coordination, including those in charge of "peer learning activities" (Lange and Alexiadou 2010). This type of research not only sheds light on the role of expertise in higher education policymaking, but also on the importance of the epistemic networks (Haas 1992) that translate European policy recommendations into national or even local practices. Interpretative accounts of the Bologna Process generally approach the question of policy convergence from a slightly different angle. In an institutionalist perspective, Musselin (2009, p. 70) claims, for instance, that the Bologna Process "did not explicitly aim at reforming higher education and research systems". Since institutional arrangements vary greatly between countries, the 
intergovernmental Bologna Process provides nothing more than a common orientation for national higher education systems. Although they acknowledge a certain degree of diversity in the domestic interpretation of Bologna reform templates such as for the Qualification Framework, other authors instead highlight the "embedded contradiction in the rhetoric of the policy documents". These documents, they argue, accept national diversity while simultaneously requiring compatibility from participants in the process (Karseth and Solbrekke 2010, p. 571). In this perspective, national variation in policy implementation is due to "the lack of shared understanding in a cultural and epistemic sense" rather than to a problem of understanding Bologna's overarching narrative (Karseth and Solbrekke 2010, p. 571). The countries of Central and Eastern Europe (CEE) provide a good example of how the Bologna Process exerts a differential impact on national reform agendas. While CEE countries share a number of features such as exposure to communism or centralized structures, they also diverge on a number of aspects. For instance, they had markedly different experiences with communism, regime change, and relationships with the EU (i.e., accession, association, or other kinds of connection). As a result, these countries, which are particularly open to European recommendations, serve as "laboratories of reform" that help to elucidate the interplay of external and domestic influences in the reshaping of higher education systems (Dakowska and Harmsen 2015). Some of them eagerly adopt European policy prescriptions, while others prefer a more selective approach to the European reform program. While the Bologna Process is sometimes presented as a set of consensual proposals whose application is left entirely in the hands of the states, several factors have reinforced its impact in new EU member states. Some of the new member states - especially those which were longmarginalized in international academic exchanges - seemed eager to be perceived as "good pupils" in the Bologna benchmarking graphs (Dakowska 2015). The fact that the Bologna Process was launched at the same time as the EU accession negotiations also explains why decision-makers in Central and Eastern European countries tended to consider its successive recommendations as part of a more general EU package (Deca 2015). Constant comparison of the progress made in various areas - with maps that distinguish the "good pupils" from the "laggards" - has increased pressure to adapt (Lange and Alexiadou 2010). Interpretive research has emphasized the existence of different reform strategies at the national level, depending on political configurations. It has expanded our understanding of the way common objectives are perceived and reframed to fit national policy priorities. Research in this tradition has also shown that, regardless of their situation as winners or losers in the 
international competition for students and researchers, most state representatives are aware of the international market for higher education and try, in their way, to play the game.

What does the Bologna Process tell us about Europeanization in higher education? For one, it stresses the importance of policy coalitions and discursive strategies in a field where EU institutions are neither the only nor the most important players. European higher education policy is the product of multiple overlapping policy arenas, policy transfers, and entrepreneurship. It is the coevolution of these different policy arenas that has led to the creation of a common coordination framework in which national policymakers may find a repertoire of reform ideas, tools, and like-minded peers that enable national change processes without enforcing predetermined outcomes. Implementation research has shown that the Bologna Process remains an asymmetrical and ambiguous reform process that especially benefits big players and older EU member states (Keeling 2006). In recent years, this type of policy coordination has become a blueprint for reform processes in other regions of the world, such as Asian, Pacific, and African countries.

\section{Conclusion}

This succinct overview of the state of research on European higher education policy stresses three important institutional specificities of EU action while, at the same time, indicating the importance of interpretive research strategies for the investigation of this policy field. First, the legitimacy of EU higher education policy is contested by the member states. Since the principle of subsidiarity constrains the European Commission to act as a sidekick to national policymakers, EU policy activities have developed in the shadow of national prerogatives and mostly concentrated on transnational topics, monitoring, and a number of influential one-time projects such as the creation of a European Network for Quality Assurance that later became a key player in the Bologna Process. Second, since the Bologna Process provided a useful platform for policymakers to develop a European agenda on their own, the EU Lisbon Strategy found itself competing with the Bologna agenda for the political attention and commitment of EU member states. Although it has been argued that the Lisbon Strategy has benefited a great deal from the Bologna Process by increasing political visibility for transnational issues and disseminating reform templates (Capano and Piattoni 2009), one might say that public attention was focused on Bologna instead of on Lisbon. Ultimately, the Europeanization of higher education has been characterized by the emergence of multiple policy arenas, stakeholders, and policy instruments, creating new opportunities for 
policymakers at both national and transnational levels. Indeed, it is the structural complexity of this policy field that renders it particularly well-suited to interpretative analysis.

\section{Bibliography}

Alexiadou, N., D. Fink-Hafner and B. Lange (2010), "Education Policy Convergence through the Open Method of Coordination: Theoretical Reflections and Implementation in 'Old' and 'New' National Contexts”, European Educational Research Journal, 9 (3), 345-358.

Alexiadou, N. and B. Lange (2013), "Deflecting European Union Influence on National Education Policy-Making: The Case of the United Kingdom”, European Integration, 35 (1), $37-52$.

Bache, I. (2006), “The Europeanization of Higher Education: Markets, Politics or Learning?", Journal of Common Market Studies, 44 (2), 231-248.

Banchoff, T. (2002), "Institutions, Inertia and European Union Research Policy", Journal of Common Market Studies, 40 (1), 1-21.

Batory, A. and N. Lindstrom (2011), "The Power of the Purse: Supranational Entrepreneurship, Financial Incentives and European Higher Education Policy", Governance, 24 (2), 311-329.

Becker, G. (1962), "Investment in Human Capital: A Theoretical Analysis", The Journal of Political Economy, 70, 9-49.

Capano, G. and S. Piattoni (2011), "From Bologna to Lisbon: The Political Uses of the Lisbon 'Script' in European Higher Education Policy", Journal of European Public Policy, 18 (4), 584-606.

Charlier, J.-E. (2009), "Faire du processus de Bologne un objet d'analyse", Education et Sociétés, 24 (2), 109-125.

Corbett, A. (2005), Universities and the Europe of Knowledge: Ideas, Institutions and Policy Entrepreneurship in European Union Higher Education Policy 1955-2005, London: Palgrave Macmillan.

Croché, S. (2010), Le pilotage du processus de Bologne, Brussels: Bruylant.

Curaj, A., P. Scott, L. Vlasceanu and L. Wilson (eds) (2012), European Higher Education at the Crossroads: Between the Bologna Process and National Reforms, vol. I, Dordrecht: Springer.

Cussó, R. (2008), "Quand la Commission européenne promeut la société de la connaissance", Mots. Les langages du politique, 88, 39-52.

Dakowska, D. (2015), "Between Competition Imperative and Europeanisation: The Case of Higher Education Reform in Poland”, Higher Education, 69 (1), 129-141.

Dakowska, D. and R. Harmsen (2015), "Laboratories of Reform? The Europeanization and Internationalization of Higher Education in Central and Eastern Europe", European Journal of Higher Education, 5 (1), 4-17.

Dale, R. and S. Robertson (eds) (2009), Globalisation and Europeanisation in Education, Oxford: Symposium Books. 
Deca, L. (2015), "International Norms in the Reform of Romanian Higher Education: A Discursive Analysis", European Journal of Higher Education, 5 (1), 34-48.

de Ruiter, R. (2010), "Variations on a Theme: Governing the Knowledge-Based Society in the EU through Methods of Open Coordination in Education and R\&D", Journal of European Integration, 32 (2), 157-173.

Ertl, H. (2006), "European Union Policies in Education and Training: The Lisbon Agenda as a Turning Point?", Comparative Education, 42 (1), 5-27.

Ertl, H. and D. Phillips (2006), "Standardization in EU Education and Training Policy: Findings from a European Research Network", Comparative Education, 42 (1), 77-91.

EUR-Lex (1957), Treaty Establishing the European Economic Community (1957), accessed 16 March 2016 at www.eur-lex.europa.eu/collection/eu-law/treaties-founding.html.

European Commission (2014): Strategic Framework. Education and Training 2020, accessed 10 October 2016 at www.ec.europa.eu/education/policy/strategic-framework_en

European Council (1992), Treaty on European Union, as assigned in Maastricht on 7 February 1992, 1992 O.J. C 191/1, accessed 16 March 2016 at www.europa.eu/eulaw/decision-

making/treaties/pdf/treaty_on_european_union/treaty_on_european_union_en.pdf.

European Council (2000), Lisbon European Council 23 and 24 March 2000: Presidency Conclusions, accessed 16 March 2016 at www.europarl.europa.eu/summits/lis1_en.htm.

Figueroa, F.E. (2008), "European Influences in Chilean and Mexican Higher Education: The Bologna Process and the Tuning Project", European Education, 40 (1), 63-77.

Fischer, F. (1995), Evaluating Public Policy, Chicago, IL: Nelson-Hall Publishers.

Foucault, M. (1966), Les mots et les choses. Une archéologie des sciences humaines, Paris: Gallimard.

Garcia, S. (2007), “L'Europe du savoir contre l'Europe des banques? La construction de l'espace européen de l'enseignement supérieur", Actes de la recherche en sciences sociales, 166-167 (1), 80-93.

Gornitzka, Å. (2010), "Bologna in Context: A Horizontal Perspective on the Dynamics of Governance Sites for a "Europe of Knowledge", European Journal of Education, 44 (5), $535-548$.

Grek, S. (2009), "Governing by Numbers: the PISA 'Effect' in Europe", Journal of Educational Policy, 24 (1), 23-37.

Haas, P. (1992), "Introduction: Epistemic Communities and International Policy Coordination", International Organization, 46 (1), 1-35.

Henry, M., B. Lingard, F. Rizvi and S. Taylor (eds) (2001), The OECD, Globalisation and Education Policy, Bingley: Emerald Group Publishing.

Heyneman, S. P. (2003), "The History and Problems in the Making of Education Policy at the World Bank 1960-2000”, International Journal of Educational Development, 23 (3), 315337.

Karseth, B. and T.D. Solbrekke (2010), "Qualification Frameworks: The Avenue towards the Convergence of European Higher Education?", European Journal of Education, 45 (4), 563576. 
Keeling, R. (2006), "The Bologna Process and the Lisbon Research Agenda: The European Commission's Expanding Role in Higher Education Discourse", European Journal of Education, 41 (2), 203-223.

Kingdon, J.W. (1995), Agendas, Alternatives and Public Policies, London: Longman.

Knodel, P., K. Martens and D. Niemann (2013), "PISA as an Ideational Roadmap for Policy Change: Exploring Germany and England in a Comparative Perspective", Globalisation, Societies and Education, 11 (2), 421-441.

Klemenčič, M. (2013), "The Effects of Europeanisation on Institutional Diversification in the Western Balkans", in P. Zgaga, U. Teichler and J. Brennan (eds), The Globalisation Challenge for European Higher Education: Convergence and Diversity, Centres and Peripheries, Higher Education Research and Policy 4, Frankfurt a.M.: Peter Lang, pp. 117138.

Lange, B. and N. Alexiadou (2010), "Policy Learning and Governance of Education Policy in the EU", Journal of Education Policy, 25 (4), 443-463.

Lascoumes, P. and P. Le Gales (2007), "Introduction: Understanding Public Policy through Its Instruments - from the Nature of Instruments to the Sociology of Public Policy Instrumentation", Governance, 20 (1), 1-21.

Lawn, M. and S. Grek (2012), Europeanizing Education: Governing a New Policy Space, Oxford: Symposium Books.

Lažetić, P. (2010), "Managing the Bologna Process at the European Level: Institution and Actor Dynamics", European Journal of Education, 45 (4), 549-562.

Martens, K. (2007), "How to Become an Influential Actor: The 'Comparative Turn' in OECD Education Policy", in K. Martens, A. Rusconi and K. Leuze (eds), New Arenas of Education Governance: The Impact of International Organizations and Markets on Education Policy Making, Basingstoke: Palgrave Macmillan, pp. 40-56.

McMahon, J.A. (1995), Education and Culture in European Community Law, London: Athlone Press.

Melo, S. (2013), "Regionalising Higher Education Transformation in Europe: What Kind of Positionality for the Council of Europe in Relation to the Bologna Process, 1999-2010", Ph.D. thesis, University of Bristol, 142-168.

Miller, P. (2001), "Governing by Numbers: Why Calculative Practices Matter", Social Research, 68 (2), 379-396.

Muller, P. and P. Ravinet (2008), "Construire l'Europe en résistant à l'UE ? Le cas du processus de Bologne”, Revue Internationale de Politique Comparée, 15 (4), 653-665.

Musselin, C. (2009), "Les réformes des universités en Europe: des orientations comparables, mais des déclinaisons nationales", Revue du MAUSS, 33 (1), 69-91.

Neave, G. (1984), Education and Training in the EU, Aldershot: Ashgate.

Niemann, D. and K. Martens (2015), "Monitoring Standards of Education Worldwide: PISA and Its Consequences", in M. Hayden, J. Thompson and J. Levy (eds), The SAGE Handbook of Research in International Education, London: Sage, pp. 488-498.

Normand, R. (2010), "Expertise, Networks and Indicators: The Construction of the European Strategy in Education”, European Educational Research Journal, 9 (3), 407-421.

OECD (2016): Education at a Glance. Paris. 
Radaelli, C.M. (2009), "Measuring Policy Learning: Regulatory Impact Assessment in Europe", Journal of European public policy, 16 (8), 1145-1164.

Ravinet, P. (2008), "From Voluntary Participation to Monitored Coordination: Why European Countries Feel Increasingly Bound by their Commitment to the Bologna Process", European Journal of Education, 43 (3), 353-367.

Ravinet, P. (2009), "La construction européenne de l'enseignement supérieur", in R. Dehousse (ed.), Politiques européennes, Paris: Presses de Sciences Po, pp. 353-368.

Scharpf, F. (2002), "The European Social Model: Coping with the Challenges of Diversity", Journal of Common Market Studies, 40 (4), 645-670.

Serrano-Velarde, K. (2014a), "Words into Deeds: The Use of Framing Strategy in EU Higher Education Policy", Critical Policy Studies, 9 (1), 41-57.

Serrano-Velarde, K. (2014b), "Rising above Institutional Constraints? The Quest of German Accreditation Agencies for Autonomy and Professional Legitimacy", Minerva, 52 (1), 97118.

Tuning educational structures in Europe (2016), What is Turning?, accessed 22 February 2016 at www.unideusto.org/tuningeu.

Walkenhorst, H. (2008), "Explaining Change in EU Education Policy", Journal of European Public Policy, 15 (4), 567-587.

Yanow, D. and P. Schwartz-Shea (eds) (2006), Interpretation and Method: Empirical Research Methods and the Interpretative Turn, Armonk, NY: M.E. Sharpe. 